\title{
THE ACTIVE IMMUNIZATION OF GUINEA-PIGS PASSIVELY IMMUNIZED WITH HOMOLOGOUS ANTITOXIC SERUM
}

\author{
By J. H. MASON, MARY ROBINSON AND P. AGERHOLM CHRISTENSEN \\ The South African Institute for Medical Research, Johannesburg
}

(With 2 Figures in the Text)

The work of Barr and her colleagues $(1949,1950,1951)$ has renewed interest in the immunization of very young babies against diphtheria. Barr, Glenny \& Randall (1950) say: 'When the level of maternally conferred antitoxin. . has fallen below 0.04 unit per $\mathrm{ml}$. at the time of the first injection [of diphtheria antigen] there is no interference with active immunization; but when this level was above 0.1 unit per $\mathrm{ml}$. immunization was unsatisfactory.' Further: 'It is suggested that all babies, except those born of potentially immune mothers further immunized during pregnancy, could be successfully immunized with three injections of prophylactic given at the ages of 3, 6 and 18 months.'

We thought that additional information would be obtained if an attempt were made actively to immunize guinea-pigs that had been passively protected with homologous antitoxic serum. The subjects, reared in our Institute, would be inbred, of about the same initial weight, subject to identical housing and feeding conditions, and available for tests at any desired time. Two probable disadvantages may be mentioned. The passive immunity conferred on the human baby in utero is almost certainly more thorough and penetrating than that attained by a guineapig $24 \mathrm{hr}$. after the intracardiac injection of homologous antitoxic serum; further, the in vitro separation of serum from the clot, its sterilization by Seitz-type pad filtration, its preservation with 'Merthiolate' and its storage might give rise to some degree of heterology. However, we felt that the advantages outweighed the disadvantages.

\section{METHODS AND EXPERIMENTAL PROCEDURE}

Guinea-pig antitoxic serum. The pooled serum of sixty guinea-pigs that had a basic immunization of two spaced doses, each of $1 \mathrm{Lf}$, of adsorbed dissolved floccules, A.D.F. (Mason, 1950) and later 6 doses of formol-toxoid, each of $50 \mathrm{Lf}$, was sterilized by Seitz pad filtration, preserved with 'Merthiolate', 1:10,000, and stored in the cold. By in vivo titration (guinea-pig intracutaneous method), it was shown to contain 60 units antitoxin $/ \mathrm{ml}$.

Passive immunization of guinea-pigs. By trial and error, the amount of this serum, injected intracardially, that would produce a circulating antitoxin titre of about $1.0 \mathrm{unit} / \mathrm{ml}$. serum $24 \mathrm{hr}$. later was found. In the experiments proper, this amount, or 1/10,1/100 or 1/1000 of it, was used. The titres actually found, expressed as geometric means, were: 1.0 unit group, $1 \cdot 16 ; 0.1$ unit group, $0.098 ; 0.01$ unit group, $0.01 ; 0.001$ unit group, $<0.001$. Throughout the text these groups will be referred to as the $1 \cdot 0$ unit, $0 \cdot 1$ unit, etc. groups. 
Active immunization of guinea-pigs. The same batch of A.D.F. was used throughout the first part of the work and the amount of antigen, $0.1 \mathrm{Lf}, 1.0 \mathrm{Lf}$, or $10 \mathrm{Lf}$, was injected subcutaneously in $0.5 \mathrm{ml}$. saline containing $5 \mathrm{mg}$. $\mathrm{AlPO}_{4}$, into guineapigs ( 10 per group) that had a passively produced circulating antitoxin titre of $1 \cdot 0$, $0.1,0.01$, and 0.001 unit $/ \mathrm{ml}$. serum and into a control, not passively immunized, group. The interval between the primary and the secondary stimulus was 4 weeks. The animals were bled at intervals and the serum of each was titrated for antitoxin at $100 \%$ increments by the guinea-pig intracutaneous method using a matured toxin capable of detecting 0.001 unit.

Control guinea-pigs. Seven guinea-pigs per group received enough homologous serum to give them, $24 \mathrm{hr}$. later, antitoxin titres of $1 \cdot 0,0 \cdot 1,0 \cdot 01$ and $0 \cdot 001 \mathrm{unit} / \mathrm{ml}$. Each was bled at the same time as the passively-actively immunized animals so that the titres of these could be referred either to the antitoxin given or to that produced as the result of active immunization. In Table 1, the immunization procedure is summarized.

Table 1. Experimental groups

\begin{tabular}{|c|c|c|}
\hline Group & $\begin{array}{l}\text { Initial passive } \\
\text { titre (unit/ml.) }\end{array}$ & Active immunization \\
\hline 1 & $0 \cdot 0$ & $2 \times 0 \cdot 1$ Lf at 4 weeks interval \\
\hline 2 & $1 \cdot 0$ & $2 \times 0.1$ Lf at 4 weeks interval \\
\hline 3 & $0 \cdot 1$ & $2 \times 0.1$ Lf at 4 weeks interval \\
\hline 4 & 0.01 & $2 \times 0.1$ Lf at 4 weeks interval \\
\hline 5 & 0.001 & $2 \times 0 \cdot 1$ Lf at 4 weeks interval \\
\hline 6 & $1 \cdot 0$ & $2 \times 1$ Lf at 4 weeks interval \\
\hline 7 & $1 \cdot 0$ & $2 \times 10$ Lf at 4 weeks interval \\
\hline $8-11$ & $1 \cdot 0-0.001^{*}$ & Nil \\
\hline
\end{tabular}

\section{RESULTS}

These are presented in graphical form in Fig. 1, the points plotted being the geometric means of the serum antitoxin titres of the guinea-pigs of each group.

In Table 2 the circulating antitoxin titres of the passively immunized animals are given 4 and 6 weeks after the injection of the serum and of the actively and of the passively-actively immunized animals 4 weeks after the primary, and 2 weeks after the secondary, stimulus.

The results given in the first and second parts of Table 2 show that initial 'passive' titres of 0.01 and 0.001 unit/ml. serum did not interfere with the production of active immunity (compare groups 1, 4 and 5) but that a 'passive' titre of $0.1 \mathrm{unit} / \mathrm{ml}$. (group 3 ) did have an adverse effect. The titre, 0.17 unit $/ \mathrm{ml} ., 4$ weeks after the primary stimulus is significantly lower $(P=0.01)$ than that, $0.56 \mathrm{unit} / \mathrm{ml}$., of the guinea-pigs of group 1 . The secondary response titre of group 3 was lower than that of group 1 but the difference between them $(3 \cdot 17$ and $5 \cdot 11$ units $/ \mathrm{ml}$. respectively) is not significant at the $5 \%$ probability level.

An initial passive titre of $1.0 \mathrm{unit} / \mathrm{ml}$. (group 2) interfered markedly with the 
production of active immunity. Four weeks after the primary stimulus, the titre was $0.073 \mathrm{unit} / \mathrm{ml}$, almost the same as that, $0.086 \mathrm{unit} / \mathrm{ml}$., of the passively immunized guinea-pigs (see third part of Table 2). Two weeks after the secondary stimulus, there was a feeble rise to $0.091 \mathrm{unit} / \mathrm{ml}$., a value, however, significantly greater $(P=0.02)$ than that, $0.027 \mathrm{unit} / \mathrm{ml}$., of the passively immunized animals. This proves that, however much the primary and/or secondary stimuli were interfered with, one or other or both did stimulate the production of active immunity.

Table 2. Serum antitoxin titres of guinea-pigs 4 and 6 weeks after passive immunization and of actively and passively-actively immunized guinea-pigs 4 weeks after the primary, and 2 weeks after the secondary, stimulus (units/ml.;geometric means)

\begin{tabular}{|c|c|c|c|c|}
\hline \multirow[b]{2}{*}{ Group } & \multirow[b]{2}{*}{ Immunization } & \multirow{2}{*}{$\begin{array}{c}\text { Initial } \\
\text { passive } \\
\text { titre }\end{array}$} & \multicolumn{2}{|c|}{ Titre after } \\
\hline & & & 4 weeks & 6 weeks \\
\hline 1 & Active only & $0 \cdot 0$ & $0 \cdot 56$ & $5 \cdot 11$ \\
\hline 2 & Passive-active & $1 \cdot 0$ & $0 \cdot 073$ & 0.091 \\
\hline 3 & 川 & $0 \cdot 1$ & $0 \cdot 17$ & $3 \cdot 17$ \\
\hline 4 & , & 0.01 & 0.64 & $6 \cdot 3$ \\
\hline 5 & ", & 0.001 & 0.8 & $4 \cdot 82$ \\
\hline 6 & ," & $1 \cdot 0$ & 0.07 & $0 \cdot 13$ \\
\hline 7 & ", & $1 \cdot 0$ & 0.08 & 0.97 \\
\hline 8 & Passive only & $1 \cdot 0$ & 0.086 & $0 \cdot 027$ \\
\hline 9 & , & 0.1 & 0.0083 & 0.003 \\
\hline 10 & , & 0.01 & $*$ & $<0.001$ \\
\hline 11 & ", & 0.001 & $<0.001$ & $<0.001$ \\
\hline
\end{tabular}

* One guinea-pig with 0.002 , two with 0.001 , and three with $<0.001 \mathrm{unit} / \mathrm{ml}$. serum.

Raising the antigen dose either 10 times, to $1.0 \mathrm{Lf}$ (group 6), or 100 times, to $10 \mathrm{Lf}$ (group 7), had no effect on the primary response, $0.07 \mathrm{unit} / \mathrm{ml}$., for the $1.0 \mathrm{Lf}$ group and $0.08 \mathrm{unit} / \mathrm{ml}$. for the $10 \mathrm{Lf}$ group, almost the same figures as those obtained for the $0 \cdot 1 \mathrm{Lf}$ group (group 2) and for the passively immunized animals (group 8). The secondary response figure for the $1.0 \mathrm{Lf}$ animals, $0.13 \mathrm{unit} / \mathrm{ml}$., was almost the same as that of the $0.1 \mathrm{Lf}$ group, $0.091 \mathrm{unit} / \mathrm{ml}$.; that of the $10 \mathrm{Lf}$ guinea-pigs was significantly higher, $0.97 \mathrm{unit} / \mathrm{ml}$.

If the experiment had been stopped at this stage, the conclusions to be drawn would have been:

(1) An initial serum titre of $1.0 \mathrm{unit} / \mathrm{ml}$. markedly interferes with active immunity production, so markedly as to render it almost valueless.

(2) An initial serum titre of $0.1 \mathrm{unit} / \mathrm{ml}$. interferes with active immunity production, markedly 4 weeks after the primary stimulus but slightly, if at all, 2 weeks after the secondary stimulus.

(3) Initial titres of 0.01 or $0.001 \mathrm{unit} / \mathrm{ml}$. do not interfere with the production of active immunity.

However, by continuing the experiment for 18 weeks a different picture was seen (Fig. 1). 
The secondary responses in groups $1,3,4$ and 5 were of the classical typegreatly in excess of the primary responses and reaching their maxima in about 14 days. Thereafter, and again classically, the titres fell precipitously in the next 4 weeks and this phase was succeeded by a 'normal' gradual fall to the 18 th week.

The serum titres of the guinea-pigs of group $7(1 \cdot 0 \mathrm{unit} / \mathrm{ml} ., 2 \times 10 \mathrm{Lf})$ followed the same pattern but at a much lower level.

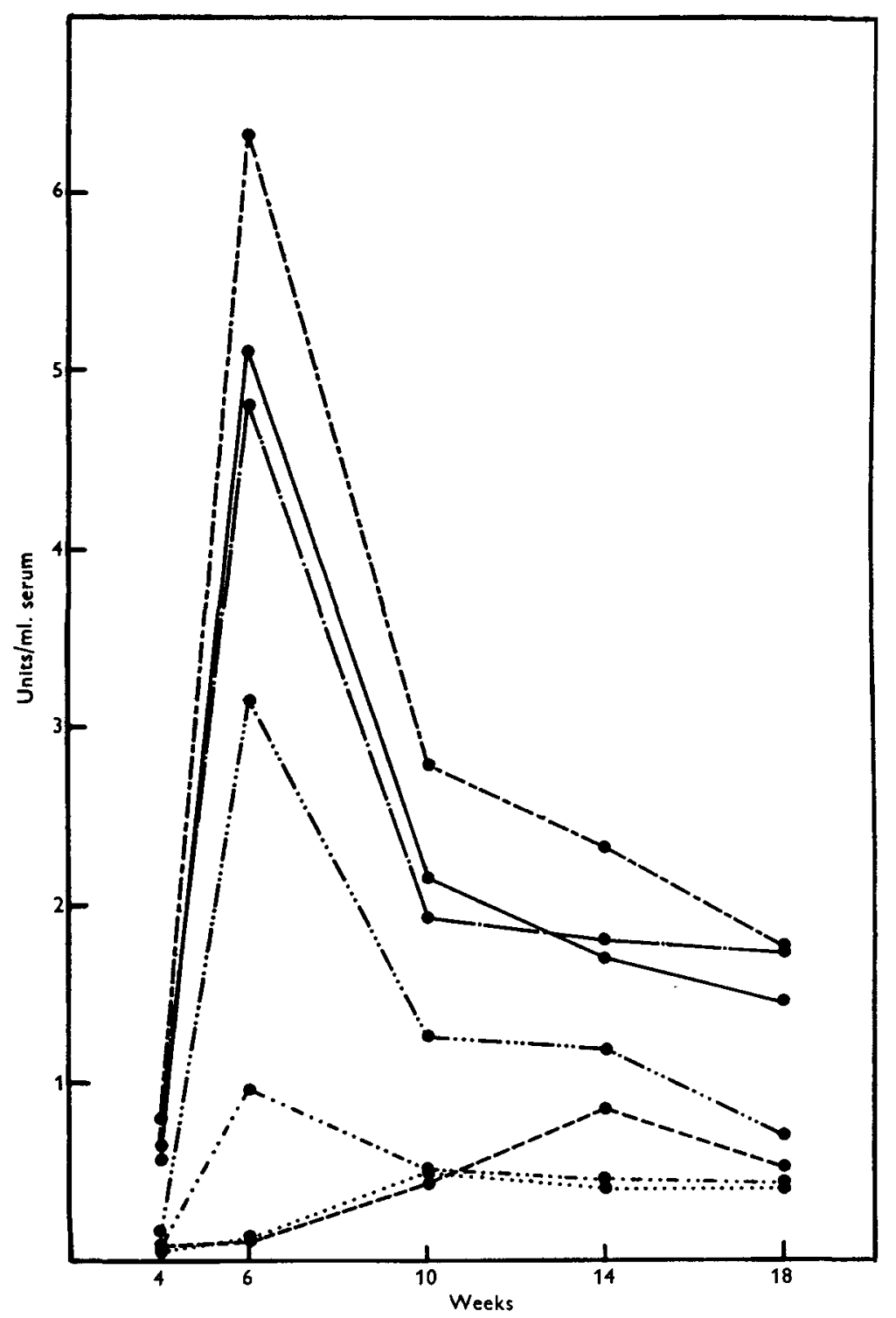

Fig. 1. Serum antitoxin titres of groups of guinea-pigs (geometric means per group) either actively or passively-actively immunized, 4 weeks after the primary, and at intervals after the secondary, stimulus. (See Table 1 for treatment of guinea-pigs.) — , group 1 ; ----- , group $2 ; \cdots-\cdots-$, group $3 ;--\cdots--$, group $4, \ldots \cdot-\cdot$, group $5 ; \cdots \cdots \cdots \cdots$, group $6 ; \cdots-\cdots-\cdots$, group 7 . 
The slopes of the curves of group $2(1 \cdot 0 \mathrm{unit} / \mathrm{ml},, 2 \times 0 \cdot 1 \mathrm{Lf})$ and group $6(1 \cdot 0$ unit $/ \mathrm{ml}$., $2 \times 1.0 \mathrm{Lf}$ ) were quite different. Instead of a fall in titre some 14 days after the secondary stimulus there was a gradual rise, with a maximum at the 14 th week in group 2 and at the 10 th week in group 6.

An analysis of variance shows that the 18th week mean titres of groups 2, 3, 6 and 7 did not differ significantly one from the other but that all were significantly lower than the 18th week titres of groups 1,4 and 5 ; these did not differ significantly among themselves.

The conclusions to be drawn from the foregoing experiments, taking the active immunization of non-passively immunized guinea-pigs as standard, are:

(1) Initial serum titres of 0.01 and $0.001 \mathrm{unit} / \mathrm{ml}$. do not interfere with the production of active immunity when the comparison is made 4 weeks after the primary stimulus and 2 and 14 weeks after the secondary.

(2) An initial serum titre of $0.1 \mathrm{unit} / \mathrm{ml}$. does interfere with the production of active immunity. This is marked 4 weeks after the primary stimulus, slight, if at all, 2 weeks after the secondary and marked 14 weeks after the secondary.

(3) An initial serum titre of $1.0 \mathrm{unit} / \mathrm{ml}$. markedly interferes with the production of active immunity at all three of these time intervals. Increasing the dose of antigen 10 times had no obvious effect, but increasing it 100 times did produce a demonstrable effect $\mathbf{1 4}$ days after the secondary stimulus. Thereafter no effect was discernible.

\section{Table 3. Experimental groups}

\begin{tabular}{|c|c|c|}
\hline Group & $\begin{array}{c}\text { Initial passive } \\
\text { titre } \\
\text { (units/ml.) }\end{array}$ & Active immunization \\
\hline $\mathbf{A}$ & $0 \cdot 0$ & $0 \cdot 1 \mathrm{Lf}$ \\
\hline B & $1 \cdot 0$ & 0.1 Lf immediately* \\
\hline $\mathrm{C}$ & $1 \cdot 0$ & 0.1 Lf 4 weeks later $\dagger$ \\
\hline $\mathrm{D}$ & $1 \cdot 0$ & $\begin{array}{l}0.1 \text { Lf immediately, } \\
0.1 \text { Lf } 4 \text { weeks later }\end{array}$ \\
\hline
\end{tabular}

* Immediately = antigen given $24 \mathrm{hr}$. after the serum injection.

$\dagger$ Four weeks later $=$ antigen given 4 weeks after the serum injection; serum samples were titrated at intervals up to the 56th week after the commencement of the experiment.

The delayed response in group 2 could have been caused by the second dose of antigen acting, really, as a primary stimulus. At the time of this injection, the passively produced titre would have fallen to about $0.1 \mathrm{unit} / \mathrm{ml}$. and no antitoxin was present that could definitely be ascribed to active immunization. To check this point, a further experiment was carried out using the same lot of homologous antitoxic serum and a different, but similar, batch of antigen.

Four groups of guinea-pigs were treated in the manner summarized in Table 3.

If the antigen injected into the guinea-pigs of group $B$ was not completely 'swamped' by the initial 'passive' titre of 1.0 unit $/ \mathrm{ml}$., an 'active' response should be noticed. Further, such a hypothetical response would be reflected in group D. The guinea-pigs of this group received two injections of antigen, one $24 \mathrm{hr}$. and 
another 4 weeks after the serum injection. If the first dose did act as a primary stimulus, the secondary response titre would be greater and continue at a higher level than the titre of the guinea-pigs of group $\mathrm{C}$, given but one antigen injection 4 weeks after conferring passive immunity.

The results are plotted (geometric means of the serum titres of guinea-pigs of each group) in Fig. 2, and from them the following conclusions may be drawn:

(1) The results obtained in group A were those that could have been anticipated -a high antitoxin titre 4 weeks after the antigen injection, a rather sharp fall in the next 4 weeks and thereafter a more gradual decline to the 56th week.

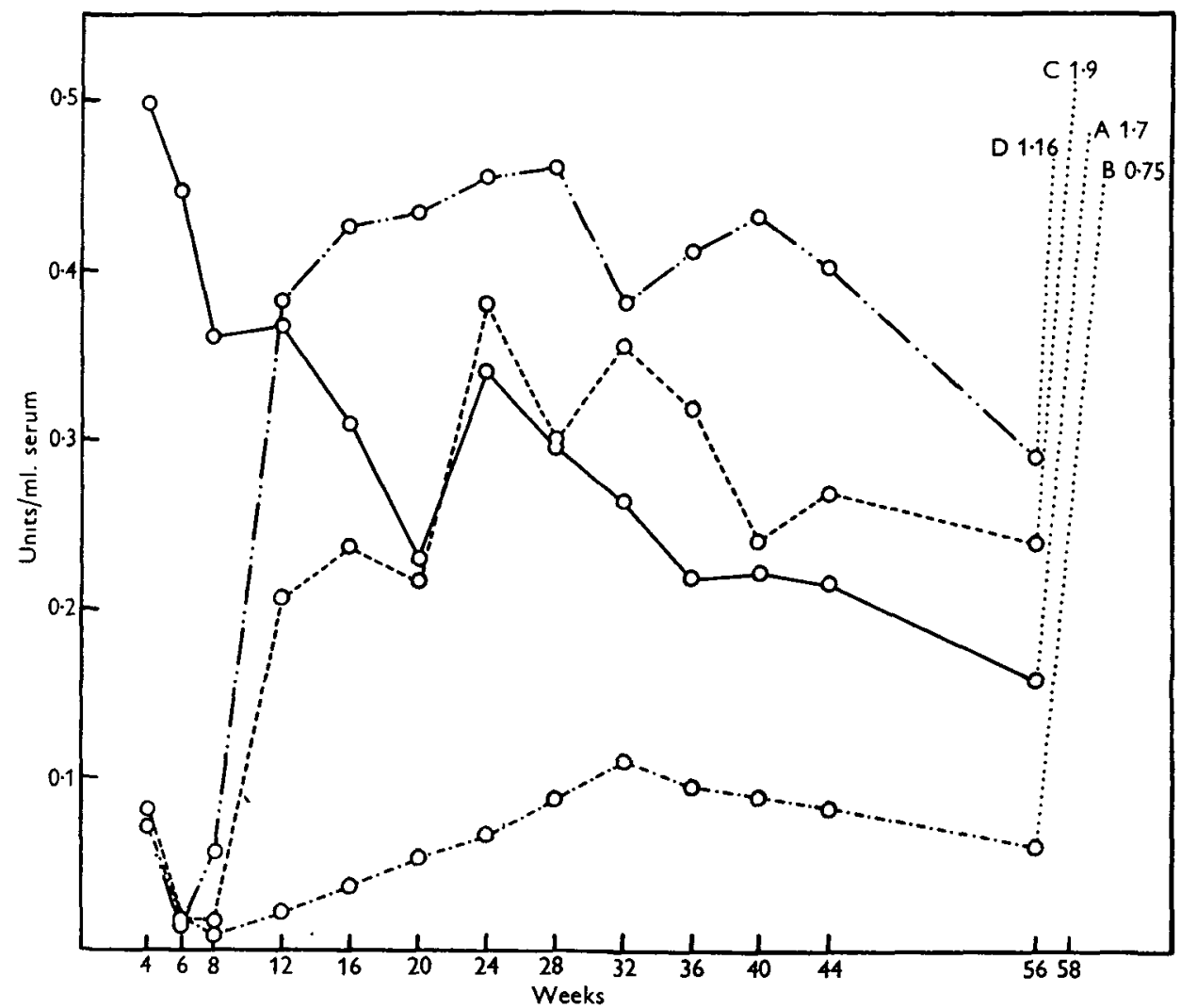

Fig. 2. Serum antitoxin titres of groups of guinea-pigs (geometric means per group), at intervals after either active or passive-active immunization and 2 weeks after a further antigenic stimulus at the 56th week. (See Table 3 for treatment of guinea-pigs). group $\mathrm{A}$; -.-...-., group $\mathrm{B}$; $--\cdots--$, group $\mathrm{C}$; $-\cdots-$, group $\mathrm{D}$.

(2) In group B, the antigenic stimulus of $0 \cdot 1 \mathrm{Lf}$ was not obliterated by $1 \cdot 0$ unit/ ml. of 'passive' antitoxin. There was a definite, albeit small, production of 'active' antitoxin, with the maximum titre at the $32 \mathrm{nd}$ week.

(3) The serum titres of group $\mathrm{D}(1 \cdot 0 \mathrm{unit} / \mathrm{ml} ., 2 \times 0 \cdot 1 \mathrm{Lf})$ were always somewhat higher than those of group $\mathrm{C}(1 \cdot 0 \mathrm{unit} / \mathrm{ml} ., 4$ weeks delay, $0 \cdot 1 \mathrm{Lf})$, and this finding suggests that the first antigen injection in group $\mathrm{D}$ may have acted as a very weak primary stimulus. Four weeks after the first antigen injection in group $\mathrm{C}$ and 
4 weeks after the second antigen injection in group $D$, traces of 'active' antitoxin were present in the sera of both lots of guinea-pigs, but it was not until some time between the 4th and 8th week after the first (group C) or second (group D) injection that titres of a higher order were attained by either group. The most that can be said is that the so-called primary stimulus in group D was of such a weak nature that it was almost negligible from a practical standpoint and that the secondary response, if a secondary response did occur, was not typical.

(4) At the 56th week, the following can be said of the titres:

(a) That of group B was significantly lower than that of any of the others.

(b) Those of groups A, C and D did not differ significantly among themselves.

At the 56th week, each guinea-pig of each group received $0 \cdot 1 \mathrm{Lf}$ of A.D.F. subcutaneously and antitoxin titrations of their sera were carried out 14 days later. The geometric means of the titres for each group are plotted in Fig. 2 and are recorded in Table 4.

Table 4. Serum antitoxin titres of guinea-pigs at the 56th week after the start of the experiment and at the 58th week, 14 days after having received $0 \cdot 1$ Lf A.D.F. (units/ml.; geometric means)

$\begin{array}{ccc}\text { Group } & 56 \text { th week } & 58 \text { th week } \\ \text { A } & 0 \cdot 16 & 1 \cdot 7 \\ \text { B } & 0 \cdot 06 & 0 \cdot 75 \\ \text { C } & 0 \cdot 24 & 1 \cdot 9 \\ \text { D } & 0 \cdot 29 & 1 \cdot 16\end{array}$

The figure for group B in column 3 of table 4 suggests strongly that the depressing effect of an initial 'passive' titre of $1.0 \mathrm{unit} / \mathrm{ml}$. serum is long-lasting. The differences in the observed titres of groups A, C and D (column 3) are not significant. The titre of group $B$ is considerably lower than those of groups A, C and D, the difference being highly significant in the case of groups $\mathrm{A}$ and $\mathrm{C}$ but, surprisingly, not significant at the $5 \%$ probability level in the case of group D.

Although the results presented in Figs. 1 and 2 are not strictly comparable because the experiments were carried out at different times with very similar, but not identical, antigens, there is evidence to suggest that, in guinea-pigs actively immunized only, the injection of the secondary stimulus 56 weeks after the primary was not nearly so effective as after 4 weeks (group 1, Fig. 1, 5.11 units/ ml.; group A, Fig. 2, 1.7 units $/ \mathrm{ml}$.). However, it must be borne in mind that those of group 1, Fig. 1, received their secondary stimulus when they weighed about $350 \mathrm{~g}$. and those of group A, Fig. 2, when they weighed about $900 \mathrm{~g}$.

\section{SUMMARY}

Groups of guinea-pigs were passively immunized against diphtheria toxin with homologous antitoxic serum so that their sera contained, at the start of the experiment, $1 \cdot 0,0 \cdot 1,0.01$ or $0.001 \mathrm{unit} / \mathrm{ml}$. respectively. They were then actively immunized with one, or two spaced, injections of $0.1 \mathrm{Lf}$ of A.D.F. Two control 
groups were included, one passively immunized only and the other actively immunized only.

Passively produced serum titres of 0.01 and $0.001 \mathrm{unit} / \mathrm{ml}$. did not interfere with active immunization in any demonstrable way.

A titre of $0 \cdot 1 \mathrm{unit} / \mathrm{ml}$. did interfere with active immunization, markedly 4 weeks after the primary, slightly 2 weeks after the secondary, and markedly 14 weeks after the secondary, stimulus.

A titre of 1.0 unit $/ \mathrm{ml}$. interfered with active immunization, markedly 4 weeks after the primary, and 2 and 14 weeks after the secondary, stimulus. This titre, however, did not completely annul the effect of the primary stimulus. The highest observed serum titre was obtained at the $32 \mathrm{nd}$, instead of at the 4 th week, as in the guinea-pigs actively immunized only.

In large measure the results confirm those of Barr and her colleagues who found that, in human babies, an initial 'passive' titre of $0.04 \mathrm{unit} / \mathrm{ml}$. serum did not interfere with active immunization, whereas a titre of $0 \cdot 1 \mathrm{unit} / \mathrm{ml}$. led to unsatisfactory immunization.

\section{REFERENCES}

Bark, M., Glenny, A. T. \& Randall, K. J. (1949). Concentration of diphtheria antitoxin in cord blood and rate of loss in babies. Lancet, ii, 324-6.

Barr, M. (1950). A cord-blood survey of diphtheria immunity. Comparison of two populations. Lancet, i, 1110-12.

Barr, M., Glenny, A. T. \& Randall, K. J. (1950). Diphtheria immunization in young babies. A study of some factors involved. Lancet, i, 6-10.

Barr, M., Glenny, A. T. \& Parish, H. J. (1951). Diphtheria antitoxin in cord-blood. Survey of samples from 15 areas of British Isles. Lancet, i, 713-16.

Mason, J. H. (1950). Alkali-dissolved diphtheria toxoid-antitoxin floccules adsorbed on aluminium carriers. J. Hyg., Camb., 48, 418-30.

(MS. received for publication 6. XII. 54) 